\title{
REVIEW \\ Katherina von Kellenbach \\ The Mark of Cain: Guilt and Denial in the Post-War Lives of Nazi Perpetrators
}

(Oxford University Press, 2013), hardcover, ix-xi + 287 pp.

Rochelle L. Millen, Wittenberg University

Philosophers, theologians, novelists, and poets have brought diverse, distinct, and dissimilar perspectives to bear upon the central human issues of $\sin$ and repentance, evil and forgiveness, justice and pardon. Yet each recognizes that existential meaning emanates and derives from our understanding of these concepts. These notions are the threads from which all interactions-individual, communal, and religious-are woven.

The contemporary novelist Marilynne Robinson is preoccupied with the "generational, genealogical succession of suffering”; Milton puts forth a $17^{\text {th}}$-century Christian understanding, while Nietzsche and Spinoza deny the possibility of repentance. Maimonides' $13^{\text {th }}$-century discussion of repentance as an essential religious and human concept is intense and analytic. And his outstanding modern disciple Joseph B. Soloveitchik devoted numerous lectures and writings to repentance as the focal issue of human identity and construction of self. Continuing this exploration, and illuminating it within a specific historical context, is the significant, profound, and meticulously researched volume by theologian Katherina von Kellenbach.

The Mark of Cain: Guilt and Denial in the Post-War Lives of Nazi Perpetrators has its roots in family history, the tale of von Kellenbach's uncle who, as a young German man in the early 1930 s, spent the war years in various positions of Nazi leadership. One of his tasks was to organize the murder of over 
18,000 Jews in Pinsk, Belarus, a mission he successfully completed. Uncle Alfred Ebner, arrested in 1962, was tried twice and eventually, after many delays, ruled incompetent to stand trial for medical reasons in 1971. Never convicted, he died a free man in 1987.

Over the years, Kellenbach's family continued to admire Ebner and to protect its familial honor. The family adopted the particular and widespread post-war German perspective that led to the lies and fabrications spun by many, including Kellenbach's father, whenever Ebner visited or was spoken about. Kellenbach's study is not only an individual attempt to cope with guilt and denial of monstrous crimes within the close family circle. It is also a subtle and insightful exploration of the Christian concepts of forgiveness and redemption, part of the cultural fabric of German-indeed, European-society.

Woven from that fabric is a juridical framework that precluded moral transformation, spiritual regeneration, and cognizance of accountability and responsibility. An outstanding aspect of Kellenbach's study is its careful research into the post-war trials of former Nazis, including the role of Christian pastors, the legal restraints, the reigning Christian conceptual theologies, and the pervading assumptions of post-war German civil society. As a German theologian who came to the United States for graduate studies (she had never met a Jew before that) and has remained here in an academic position, Kellenbach sees the Holocaust as "an important case study of the power of antisemitism, racism, nationalism, and ethnic hatred [which also] provides lessons for turning painful histories into common ground from which to shape different futures" (p. xi).

The biblical narrative of Cain and Abel is the framing metaphor for Kellenbach's extraordinary exploration of guilt, denial, forgiveness, memory, redemption, and moral responsibility. While Christian theology viewed the mark of Cain as a divine stigma upon Jews for allegedly murdering Jesus, thus condemning Jews to perpetual servitude and wandering, 
Kellenbach reinterprets the text in startling fashion. The mark of Cain, as a public signifier of his guilt, indicates God's protection. Cain's readily transparent guilt precludes the erasure of memory, creating an unbreakable link between redemption and memory.

In her telling, his mark is not a sign of shame, but rather of the possibility of change and redemption. Memory of fratricide becomes the foundation of moral transformation. Cain's second chance is founded on guilt from his past deed, leading toward acceptance of responsibility and respect for the memory of Abel, his brother. As he evolves, indifference becomes respect, entitlement changes to empathy, and invulnerability becomes integrity. The Christological, antiJewish readings of the Cain narrative are transformed into a remarkable (and in many ways rabbinic) protocol for moral renewal: spiritually, practically, and juridically. Kellenbach reads the story of Cain as a counter-narrative to that of the Prodigal son, one which "encapsulates the task incumbent upon perpetrators" (p. 15), her uncle among them. Her work makes palpable the shadow of guilt which haunts German families.

The crimes committed by the Nazis and their many cohorts cannot be expiated by judicial punishment alone; there is no adequate payment of the moral debt of brutal murder. This of course was the much debated issue when Germany offered reparations to the survivors of Nazi atrocities. Kellenbach asserts that despite the soteriological claims of traditional Christian theology, "there are some burdens of guilt that cannot be removed either by forgiveness or punishment" (p. 9). Any declaration of closure regarding the events of the Shoah is a form of escapism. Rather, the challenge and task of the perpetrators-individually, communally, and culturally-is to "shoulder the legacy of perpetration" and face the reality of collective evil and its agents, even now, seventy years later. Only such a process can lead to the moral transformation through which genuine goodness might triumph in human struggles. Reconciliation and responsibility are lifelong projects, deriving 
from conscious memory of evil, hence, her use of the biblical Cain narrative as her framework.

Kellenbach, in detail and in lucid sentences, carefully traces the various stages through which individual perpetrators and post-war German society attempted to deal with the central issues of guilt and denial. Her exploration challenges important aspects of Christian theology, and in my view, approaches the complex rabbinic understanding of repentance as pivotal to the human experience, especially in the face of ideological, brutal evil. There must be acknowledgement of personal responsibility and palpable remorse.

The amnesty campaign in Germany following the war, the War Criminal Prison of Landsberg, the Stuttgart Declaration, the cases of Oswald Pohl and Robert Mulka: each is analyzed in order both to demonstrate their legal and theological limitations and to develop the context for Kellenbach's conceptions of justice and moral transformation. In the chaos immediately following the war, the churches were perhaps the single most organized institutions in Germany that might speak for-and indeed to-the German people. Yet church documents tended to critique what they termed "collective guilt" and emphasize the sinfulness of all humanity. That is, they did not urge the perpetrators and bystanders to acknowledge their deeds-or lack thereof-since all persons are sinners. And if wrongdoing were indeed recognized, Christian forgiveness would readily be forthcoming. Some pastors argued for a general amnesty, noting a shared sense of guilt which would preclude the introspection necessary for acknowledging personal responsibility. The result? 5,025 perpetrators were tried in the Western Allied zones between 1946 and 1949. The death penalty was imposed on 806, 486 of whom were executed. The vast majority were sentenced to life in prison and later given amnesty. By 1958, Landsberg Prison was empty.

Kellenbach vividly describes how, during these post-war years, the internment camps and the Allies' legal system were overwhelmed in many ways. This led the German Roman Catholic 
and Evangelical (Protestant) churches to organize Christian reeducation programs and provide both practical and moral support to those awaiting trial. That they had, in the main, supported the policies of National Socialism's was pushed aside in their enthusiasm to remake souls, to garner new converts, to have well-attended religious services, and to open hearts to the good news of Christianity. Kellenbach traces the religious evolution of Martin Niemöller; the role of the October 1945 Stuttgart Declaration of Guilt, which did not specify acts of wrongdoing, nor name either culprits or victims; and the persistent and aggressive denial of personal culpability that would echo across German discourse for decades. Subsequent documents, such as the request that the Landsberg inmates receive amnesty, were based on prioritizing Christian forgiveness over justice. The need to look back and examine the past was painted over with a veneer of Christian forgiveness. In a secret 1949 memorandum of the Evangelical Church criticizing postwar prosecutions of Germans, verses from Romans 3 were explained to mean that righteousness was a matter of faith, not of moral action: "The blood of Christ purifies 'quite apart from the law" (pp. 58-59). One could participate in atrocity, be reconciled to the church, thus be absolved from any guilt, and move forward. In this trajectory, the memory of victims was lost.

The Stuttgart Declaration so enraged some in Germany that Pastor Martin Niemöller, an initiator of the document, became a lightning rod for widespread and pervasive criticism. He emphasized personal responsibility-through omission or commission-while the general public insisted on its commitment to duty and sacrifice. They failed to see the connection between Nazi values and Nazi atrocities. The declaration linked Christian confession with forgiveness and absolution, thus strengthening the argument for amnesty.

Using the declaration as its basis, the secret memorandum of the Evangelical Church altered the focus of the Stuttgart Declaration and, surprisingly, had Niemöller's imprimatur. It criticized the legal authority of the Nuremburg Tribunal; it 
altered the contrition and humility articulated in the original to express a sense of opposition and entitlement. Collective culpability precluded individual moral repair, and the victims remained a nameless mass.

Oswald Pohl, one of the last seven men hanged at Landsberg in June, 1951, is a paradigm of the easy comfort many perpetrators sought in religion, regardless of the atrocities for which they were responsible. In Pohl's 1950 memoir, probably cowritten with the priest who aided his conversion to Catholicism, Pohl writes of his seeking "inner peace" and never once accepts personal responsibility or articulates remorse for the death of the millions of victims in whose murders he was complicit. "I never killed anybody," he asserts, although he worked closely with Himmler and oversaw the economic and industrial aspects of the extensive slave labor system in the concentration camps. To the end, he affirmed his devotion to fatherland and lamented the "catastrophe" not of the murder of millions but of Germany's loss of the war. There is but one indirect reference. Pohl writes "not much remained hidden from me, even if I did not participate in it personally" (pp. 9091). Pohl whitewashes his powerful role in mass murder, but holds others accountable.

An almost mystical conversion to Catholicism left Pohl feeling a clean break with his past, a lifting of unnamed sins as he sensed a rebirth into the universal church. Kellenbach ironically renames such conversion as "get out of purgatory free" cards (p. 93) that eliminated repentance and contrition as necessary conditions for joining the church. Attaining "inner peace” was readily accomplished, a journey denied in any form to Pohl's victims. It is interesting that Kellenbach sees Pohl's attraction to Catholicism as a variant of the allure he found in Nazism; both were characterized by unconditional obedience, strict rules, a command structure and hierarchy, and a black and white understanding of ethics and texts. Pohl's militaristic inclinations were a factor in the integration of Catholicism into his worldview. 
I find incredible and fascinating that many of Pohl's supporters, among them Konrad Adenauer, appealed to the pope to intervene and spare Pohl's life (p. 96). Pohl's final words, and those of his priest, offer eternal rest to those who continue to "live in hatred," an obscene way of blaming the victims, none of whom would consider the "rest" put forth as anything but false in every way.

Another case of factual and theological conflation is that of Robert Mulka, deputy commander of Auschwitz between April 1942 and March 1943. Tried in the Frankfurt Auschwitz trial of 1963-1965, Mulka expressed regret and condemned, "as a Christian," the "terrible things" that had occurred. Yet he denied all evidence brought in court, seeing himself as a victim of persecution and harassment. Rather than individual criminal responsibility, he spoke of the political realm, the ideology of the nation, which, to his surprise, turned out to be mistaken to some. It is as if he was surprised that murdering human beings was now considered a crime (p. 132).

The records Kellenbach so carefully examines make clear that many, complicit in mass murder fueled by ideology, embraced denial and justification, often relying on a facile sense of Christian forgiveness to whitewash their deeds. Others, a much smaller number, continue to pursue acts of penance, which regenerate human connection. Germany, so long haunted by its grim history, has to a large extent taken upon itself the mark of Cain as a sign of its commitment to moral repair. As Elizabeth Kolbert states in a recent essay ("The Last Trial," The New Yorker, Feb. 16, 2015), "There was never going to be justice for the Holocaust, or a reckoning with its enormity." Perhaps even the mark of Cain is inadequate in the face of widespread atrocity. But, as Kellenbach demonstrates, it is the sole strategy which might lead us to look deeply into the face of the Other, seeing the image of God and the essence of all personhood.

This outstanding historical and theological study has but one editorial error: on page 195, "cease" appears instead of 
"seize." Kellenbach's book clearly conveys the Christian theological protocols used after the Shoah to diminish individual and collective guilt. Her reconceptualization of the biblical tale of Cain provides a penetrating and insightful framework through which to probe guilt, denial, repentance, forgiveness, and justice in a world in which-alas-atrocities continue to occur. I highly recommend her study. 